\title{
FIRE PREVENTION STRATEGY FOR BUILDINGS IN CONSTRUCTION
}

\author{
Chun-Shing Yeh ${ }^{1}$, Ban-Jwu Shih ${ }^{2}$ and Chuan-Wei $\mathrm{Wu}^{2}$ \\ ${ }^{1}$ Fire Department, Taipei City Government, Taipei, Taiwan, ROC \\ ${ }^{2}$ Associate Professor, Department of Civil Engineering, National Taipei \\ University of Technology, Taipei, Taiwan, ROC
}

\begin{abstract}
The purpose of this paper is to raise the standards of construction quality and to promote a safer construction environment for the working labor. So far, very little work has been done in this field in Taiwan. Therefore, this research will focus on case studies to determine the most likely factors that give rise to fires during building constructions. Both the systematic approach and the field survey will be used to formulate a proper strategy to prevent the fire hazard, and the results can be used by contractors and construction managers to address the trade-specific needs of education and training.
\end{abstract}

Keywords: fire hazard, construction, case studies, risk factors, construction fires

\section{INTRODUCTION}

According to the statistics of the National Fire Administration of Taiwan, there were 1,273 cases of fires due to negligence in construction from 1992 to 1999 [1], and the number is increasing by the year. If small fires such as those started by faulty appliances and cigarette butts are included in the statistics, the number will be even more alarming. From experience it is found that careless behaviors and faulty equipment are the main causes of fires on most construction sites. Therefore, most of these fires could have been prevented if more precautions had been taken.

The purpose of this paper is to create a safer working environment and improve the construction fire management. In order to reduce the fire hazards during building constructions, it is necessary to perform the "Construction Safety Assessment" before the construction starts to better understand the potentially dangerous construction procedures on the construction sites. Then, it is also necessary to conduct the "Fire Risk Analysis" to provide a hazard index for the management to enforce the safety precautions such as the "Self Voluntary Inspections" during constructions. Combined with the execution of emergency plans such as the "Self-reliance FireFighting Programs," it is then possible to escape from fires when they do occur. For this reason, it is clear that in order to prevent losses due to fires the most important tasks for construction fire management are the implementation of proper safety operation procedures and the improvement of job site management.

\section{THE STUDY OF CONSTRUCTION FIRE RISKS}

The study of construction fire risks is best illustrated by case studies as shown below.

\subsection{Case analysis}

Two famous case studies are presented here:

Case 1: Fire of the Grand Hotel in Taipei

The Grand Hotel is a 12-story reinforced concrete building with a lot size of $164,597.5 \mathrm{~m}^{2}$. It was built in 1974, and has been a well-known hotel in the world with its splendor exterior. The unlikely fire broke out at 11 o'clock on June 27, 1995 due to the negligence of welding workers repairing the northwest corner of the hotel's roof. A picture of the fire is shown in Picture 1.

The workers could not extinguish the fire when it started, and the fire spread with the help of strong southwest wind. As a result, the entire 12th floor was burned, and the property loss exceeded 100 million N.T. dollars. During the fire, five persons were injured including three firefighters, one construction worker, and one hotel employee. This fire cost the Grand Hotel its reputation, and the subsequent repair turned out to be very expensive and time-consuming.

This fire exemplified the following problems:

1. The construction workers lacked the proper training on preventing fire hazards and the 
handling of flammable materials.

2. The subsequent fire investigation found evidences of cigarette smoking on the job site, and the investigation did not rule out cigarette smoking as the cause of the fire. Apparently the foreman did not make sure that everyone abides by the nonsmoking rules.

3. The automatic sprinkler system was turned off for the construction. Other safety measures were not in place to replace the sprinkler system.

4. Although fire extinguishers were used to put out the fire, they were not the right extinguishers for the type of fire that occurred.

5. The hotel used flammable instead of fire resistant materials for decoration, and the floors were not segmented for fire safety. When the fire broke out, it quickly spread.

6. The hotel and the contractor did not conduct the fire risk analysis, and they allowed the flammable material (wood, ceiling materials, and paints) to be piled up near hot work such as welding.

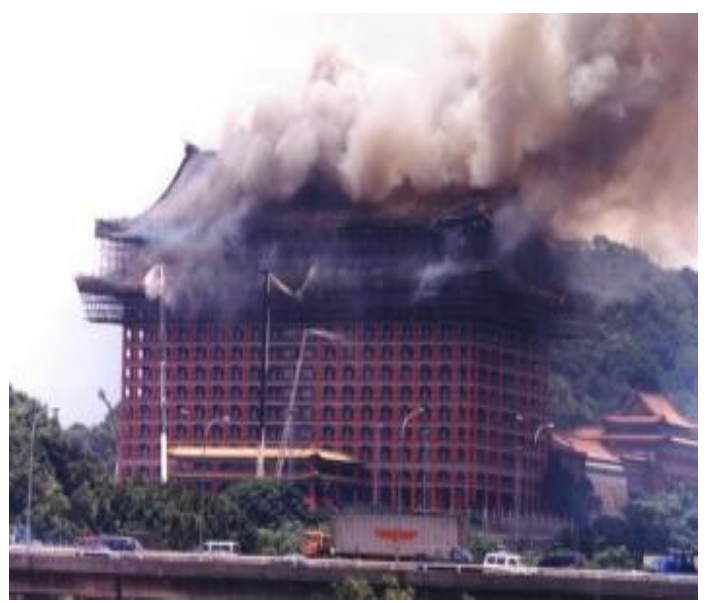

Picture 1. A fire caused by construction negligence of Grand Hotel in Taipei on June 27, 1995.

Case 2: Fire of the Tuntex skyscraper in Kaohsiung

The Tuntex skyscraper is located in the Kaohsiung City. It is a multipurpose building with 85 stories of steel structure above ground and five stories of reinforced concrete structure as basements. It is also the tallest building in Kaohsiung. When the building was being constructed, there were four fires broken out due to construction negligence-the January 28, 1997 fire on the $59^{\text {th }}$ floor, the May 11, 1997 fire on the $59^{\text {th }}$ floor, the March 27, 1998 fire on the $14^{\text {th }}$ floor, and the July 15,1998 fire on the $40^{\text {th }}$ floor. In addition to these reported fires, there were also fires that went unreported to the fire department. All combined, it is astonishing how frequent that fires broke out at this building, and it greatly undermined the construction quality, the construction schedule, and the business reputation. Luckily that the building was not open to the public at the time, or severe casualties could have been resulted.

This fire exemplified the following problems:

1. The construction workers were not sufficiently trained on fire hazard prevention, and they did not follow the standard operation procedures on electric welding. Also, they became panic when the fire broke out.

2. If the current practice continues there will be increasing number of fires when the interior decoration starts and the flammable materials piles up.

3. There were four repeated fires during the construction of this building. It clearly showed that the fire management was not taken seriously and no effective fire prevention measures were in place.

4. In order to avoid bad publicity, the contractor of the Tuntex building intended to put out the fire alone. As a result, reporting fires to the fire department was delayed.

5. High rise buildings present special fire risks. It is difficult to extinguish fires, and the fires tend to spread quickly.

\subsection{The analysis of risk factors}

When a building is being expanded, remodeled, repaired, decorated, or redecorated, it is frequently necessary to perform hot work such as welding and soldering. Under such circumstances, fire could easily be started by careless workers with welding sparks or naked flames. If the no-smoking rule is not strictly enforced or arson is involved, the chances of fires greatly increase. This is especially dangerous for places that are open to the customers whiling remodeling is taking place. During this period, the building's fire protection may be compromised. The likelihood of igniting a fire is greater because the construction usually requires the use of high temperature equipment and the construction site is usually full of flammable materials such as paints and solvents.

The are usually a number of factors that contribute to the occurrence of a fire. Especially for major fires, there are usually good reasons behind them. Hence, if we can carefully analyze the risk factors involved, we can implement better safety precautions to prevent the fires. Base on our experience and past case histories, we conclude that the main causes of construction fire can be classified as human errors or equipment problems. These errors and problems are shown in Fig. 1, Table 1, Fig. 2 , and Table 2, respectively. 


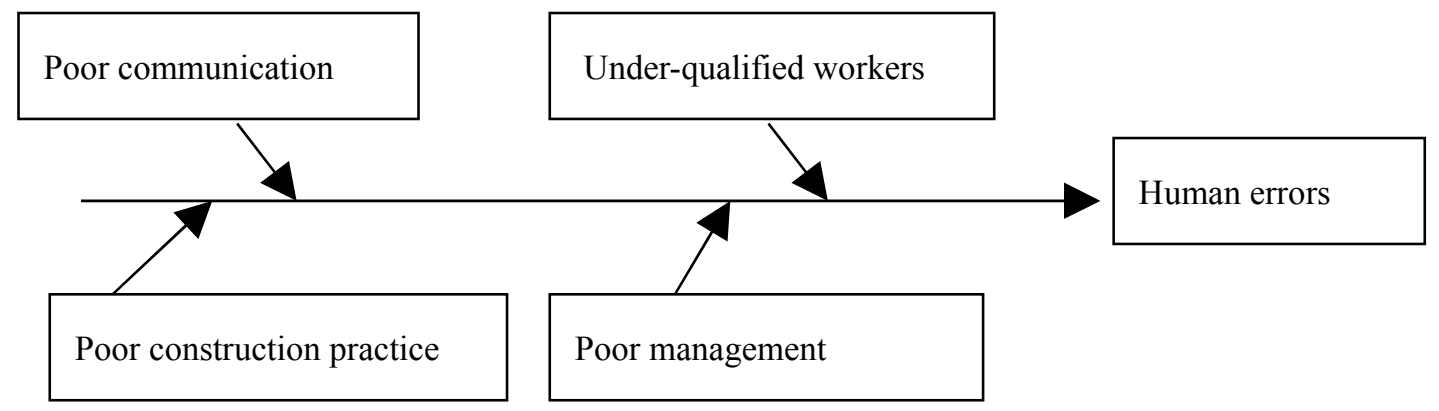

Figure 1 Flow chart of human errors

Table 1: Types of human errors

\begin{tabular}{|c|c|c|c|}
\hline Under-qualified workers & Poor Management & Poor construction practice & Poor communication \\
\hline $\begin{array}{l}\text { 1. Insufficient fire } \\
\text { prevention knowledge } \\
\text { 2. Insufficient } \\
\text { understanding of the } \\
\text { characteristics of } \\
\text { construction materials } \\
\text { 3. Poor physical } \\
\text { conditions } \\
\text { 4. Fatigues from over- } \\
\text { working } \\
\text { 5. Inexperience }\end{array}$ & $\begin{array}{l}\text { 1. } \begin{array}{l}\text { Tossing cigarette butts } \\
\text { on the construction sites }\end{array} \\
\text { 2. No self-reliance fire- } \\
\text { fighting ability } \\
\text { 3. No job site } \\
\text { superintendents } \\
\text { 4. No safety inspections } \\
\text { 5. } \text { No fire prevention } \\
\text { measures } \\
\text { 6. Unprofessional working } \\
\text { attitudes }\end{array}$ & $\begin{array}{ll}\text { 1. } & \text { Not following the } \\
& \text { operation procedures } \\
\text { 2. } & \text { Using untrained staff } \\
\text { 3. } & \text { Inexperience operators } \\
\text { 4. } & \text { Negligence of seasoned } \\
& \text { operators }\end{array}$ & 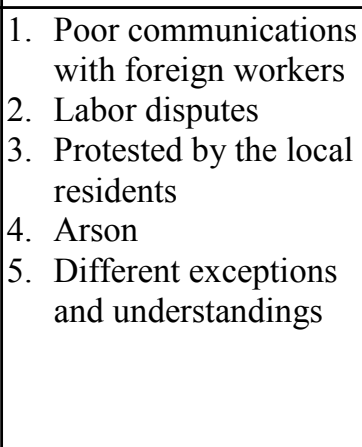 \\
\hline
\end{tabular}

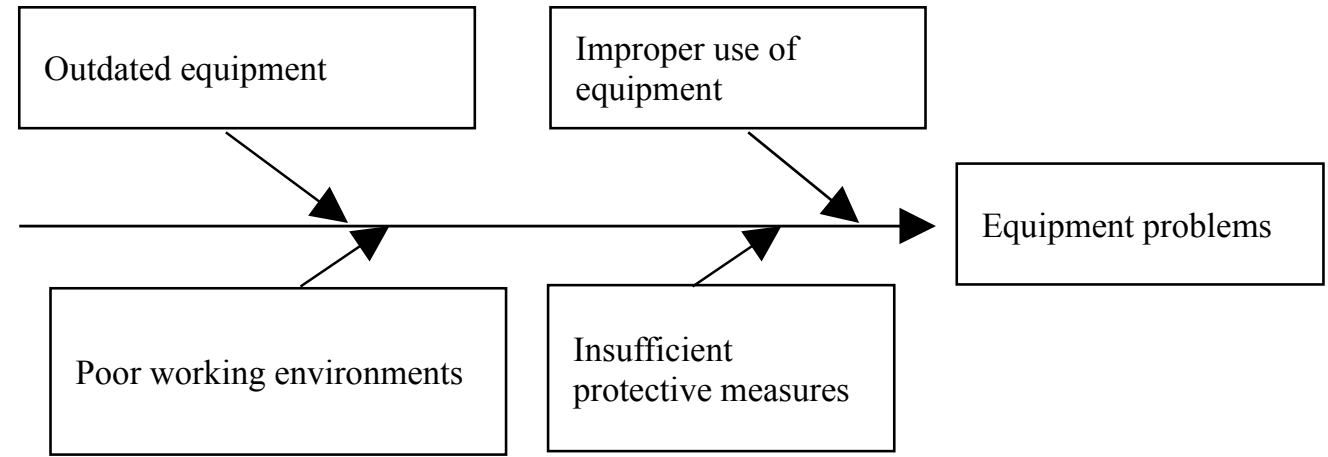

Figure 2: Flow chart of equipment problems

Table 2: Types of equipment problems

\begin{tabular}{|c|c|c|c|}
\hline Improper use of equipment & $\begin{array}{c}\text { Insufficient protective } \\
\text { measures }\end{array}$ & Outdated equipment & Poor working environments \\
\hline $\begin{array}{l}\text { 1. Poor cooperation } \\
\text { 2. Using wrong equipment } \\
\text { 3. Not following the } \\
\text { standard operating } \\
\text { procedures }\end{array}$ & $\begin{array}{ll}\text { 1. } & \text { Heat } \\
\text { 2. } & \text { Sparks } \\
\text { 3. } & \text { Insufficient safety } \\
\text { precautions } \\
\text { 4. } \\
\text { Early removal of fire- } \\
\text { fighting equipment } \\
\text { 5. } & \text { Unclearly marked signs }\end{array}$ & $\begin{array}{ll}\text { 1. } & \text { Erosions } \\
\text { 2. } & \text { Wear and tear } \\
\text { 3. } & \text { Poor maintenance } \\
\text { 4. } & \text { Insufficient strength } \\
\text { 5. } & \text { Gas leaks }\end{array}$ & $\begin{array}{l}\text { 1. Misplaced equipment } \\
\text { 2. Disorganized } \\
\text { construction materials } \\
\text { 3. Stockpiling of } \\
\text { flammable materials } \\
\text { 4. No fire segmentations }\end{array}$ \\
\hline
\end{tabular}

\section{THE STUDY OF FIRE PREVENTION STRATEGY}

In order to reduce the fire risks of building constructions, it is recommended that the "Construction Safety Assessment" be conducted before the construction starts to better understand the potentially dangerous construction procedures on the construction sites. Then, the "Fire Risk Analysis" should be conducted to provide a hazard index for the 
management to enforce the safety precautions such as the "Self Voluntary Inspection" during construction [2]. Combined with the execution of emergency plans such as the "Self-reliance Fire-Fighting Programs," it is then possible to escape from fires when they do occur. The process is also illustrated as a flow chart as shown in Fig. 3.

\begin{tabular}{|c|c|c|c|}
\hline $\begin{array}{l}\text { Construction } \\
\text { safety assessment }\end{array}$ & $\begin{array}{l}\text { Fire risk } \\
\text { analysis }\end{array}$ & $\begin{array}{l}\text { Self voluntary } \\
\text { inspections }\end{array}$ & $\begin{array}{l}\text { Self-reliance Fire- } \\
\text { fighting programs }\end{array}$ \\
\hline
\end{tabular}

Figure 3: A flow chart of fire-fighting strategies

\subsection{Construction safety assessment [3]}

The following are to be considered for the construction safety assessment:

\subsubsection{Implementation of construction plans \&} construction site policies:

After the building contractor was offered the job, the contractor should immediately prepare for the construction, call a meeting to discuss the construction plans, and draft rules for the construction site.

\subsubsection{Preliminary risk analysis before construction}

Before implementing the construction plans, the design engineers should meet with professional engineers and safety specialists to review the potential hazards on the construction site based on the construction environments, methods, equipment, supplies, and personnel.

\subsubsection{Review of safety codes and regulations}

Review and reexamine the contents of the "Worker Safety Management Plan" and the "Worker's Safety Procedures for Specific Jobs" in accordance with the labor safety laws \& regulations and construction standards.

\subsubsection{Evaluation of specific fire hazards}

Assess the probability of major accidents such as building collapses, excess amount of groundwater, and fires.

\subsubsection{Revision of construction plans}

Revise the construction plans according to the results of above evaluations.

\subsection{Fire risk analysis}

It is necessary to have a good understanding on the equipment, supplies, operation environments, and construction procedures to discover potential fire risks and to pinpoint the most critical factors. Then, special considerations can be made to reduce the fire hazard. In practice, the fire risks are divided into high risk factors and low risk factors, and the emphasis is placed on the high risk factors. Precautions and fire safety measures such as tradespecific training, standard operating procedures, safety signs, and preventive maintenance of equipment should be in pace. This process is shown as a flow chart in Fig. 4.

\subsection{Self voluntary inspections}

Self-voluntary inspection refers to the activities performed by the contractor to understand the work site fire hazard and to adopt the necessary measures. If the contractor has performed the construction safety evaluation and studied the fire hazard in advance, he should be able to compile a checklist for voluntary inspections. Based on this checklist, regular and random inspections of the construction site should be made by the site superintendents and project managers.

\subsection{Self-reliance fire fighting programs}

The risk of a major fire is greatly reduced if the above steps are followed by the contractor. However, this does not mean that fires will never occur. To avoid panic when a fire does break out, the contractor should implement the self-reliance fire-fighting program. The basic program should include monitoring units, fire-fighting units, and emergency escape units. In addition, fire prevention units and emergent care units can be added to the program if necessary.

\section{CONCLUSIONS AND SUGGESTIONS}

The careless behaviors, unsafe environments, and dangerous equipment are the main factors that contribute to a fire. All of them can be and should be avoided. Therefore, this paper suggests that by executing the fire management strategy of "Construction Safety Assessment, Fire Risk Analysis, Self-voluntary Inspection, and Self-reliance Firefighting Program" during the construction process, the likelihood of a fire can be minimized. Together with complete fire insurance policies, the potential loss and injuries due to a fire can be greatly reduced. 
We have the following suggestions:

(1) Encourage the development of automated construction equipment to reduce the possibility of human negligence.

(2) Maintain the fire fighting equipment at working order anytime during the construction, and apply the automatic fire alarms and monitoring system.

(3) Establish computer databases of construction workers, machinery, equipment, fire-fighting equipment, and emergency care equipment.

(4) Increase the amount of incentive and bonus to contractors with good records of construction fire management.

(5) Standardize the operating procedures of construction.

(6) Encourage the contractors to replace the handheld fire extinguishers with the more efficient portable fire extinguishers.

(7) Had the Grand Hotel and the responsible contractor not purchased the billion N.T. dollar insurance policy for the repair work, it would not have been possible to rebuild the historic Grand Hotel. Based on this experience, we think that the insurance system is valuable and needs to be reinforced.

\section{REFERENCES}

[1] Wu, J.-P., "The Study and Analysis of Industrial Fire Hazard," Modern Fire Fighting Magazine, Vol. 88, pp. 11, 2000.

[2] Lin, C.-Y., "The Current State and Prospects of Automatic Inspection Systems," Labor Administration Magazine, Vol. 141, pp. 8, 2000.

[3] Chang, J.-C., "Introduction of Construction Safety Evaluation," Labor Administration Magazine, Vol. 141, pp. 13-17, 2000.

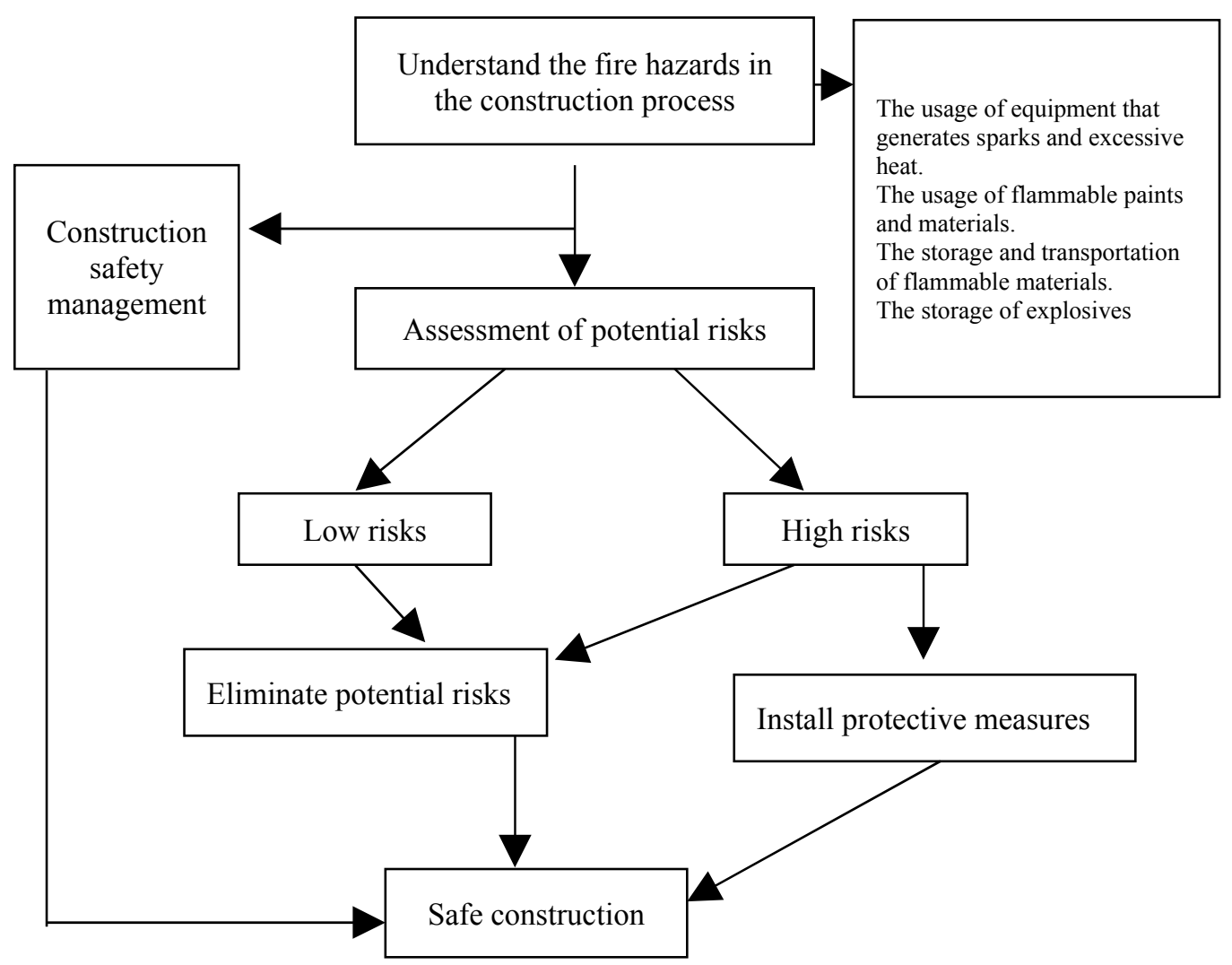

Figure 4. Fire risk analysis and prevention flowchart 